\title{
ANTIMUTAGENIC ACTIVITY OF BINARA HERBS (ARTEMISIA VULGARIS L.) ETHANOL EXTRACT IN MALE MICE INDUCED BY CYCLOPHOSPHAMIDE
}

\author{
LINTA MELIALA, URIP HARAHAP*, AMINAH DALIMUNTHE
}

Department of Pharmacology, Faculty of Pharmacy, Universitas Sumatera Utara, Medan, Indonesia. Email: urip@usu.ac.id

Received: 08 December 2017, Revised and Accepted: 05 January 2018

\section{ABSTRACT}

Objectives: This study aims to evaluate the antimutagenic activity of binara herbs (Artemisia vulgaris L.) ethanol extract on male mice.

Methods: Binara herbs powder was extracted is used ethanol $96 \%$ by maceration, then made into a suspension preparation used $0.5 \%$ carboxymethylcellulose with 3 dose variations $(100,200$, and $300 \mathrm{mg} / \mathrm{kg})$. Further, the extract was administrated orally in mice for 7 consecutive days. $4 \mathrm{~h}$ after the last orally, cyclophosphamide $50 \mathrm{mg} / \mathrm{kg}$ IP was injected. $30 \mathrm{~h}$ after cyclophosphamide injection, the animals were killed, and the samples of bone marrow were prepared and stained with gems. For each sample, 200 cells of polychromatic erythrocytes (PCE) and the same number of normochromatic erythrocytes (NCE) and the cells containing their micronucleus (MN) were counted using the MN test method in vivo.

Results: Cyclophosphamide increased the frequency of MnPCE and decreased cell proliferation (PCE/PCE+NCE). All doses of extracts significantly reduced the frequency of $\mathrm{MnPCE}(\mathrm{p}<0.05)$. The cell proliferation ratio (PCE/PCE+NCE) was also increased. The most effective dose is $300 \mathrm{mg} / \mathrm{kg}$ because it has the greatest ability to decrease the frequency of MnPCE and increase the cell proliferation ratio.

Conclusion: Results of this study indicated that binara herbs (A. vulgaris L.) ethanol extract has potent antimutagenic activity.

Keywords: Binara herbs, Antimutagenic, Micronucleus test.

(C) 2018 The Authors. Published by Innovare Academic Sciences Pvt Ltd. This is an open access article under the CC BY license (http://creativecommons. org/licenses/by/4. 0/) DOI: http://dx.doi.org/10.22159/ajpcr.2018.v11i4.24176

\section{INTRODUCTION}

Gene mutation is the cause of congenital metabolic defects in cellular systems, lead to morbidity and mortality in living organisms. A plethora of synthetic and natural substances, apart from various genetoxic physical and biological agents are known to act as mutagenic agents [1]. Mutagen is a substance that can induce deoxyribonucleic acid (DNA) into mutations. Cyclophosphamide is one of the chemotherapeutic agents used for the treatment of various cancers, such as acute and chronic leukemia and malignant lymphoma. This agent can also be indicated for autoimmune diseases, in spite of its approved cytotoxicity and clastogenic properties. This compound is toxic, due to its alkalizing effect and creation of a crosslink between the two strands of DNA, breaking the DNA and protein synthesis inhibition [2]. In the liver, cyclophosphamide is converted to aldophosphamide by the cytochrome P-450 enzyme. Then, aldophosphamide is converted to its active metabolites phosphoramide mustard and acrolein, spontaneously [3]. Phosphoramide mustard has antineoplastic effect; while acrolein interferes with tissue antioxidant defense system, which leads to the formation of free radicals and has many toxic effects such as cell death apoptosis, necrosis, and tumorogenesis [4]. Free radicals are unstable structures that can damage DNA molecules and finally cause mutation [5].

One of the plants that are known to contain flavonoids is Binara herb (Artemisia vulgaris L.). A. vulgaris L. is an Asteraceae family plant, composed of over 500 species spread all over the world. The constituents Artemisia sp. such as terpenoids, flavonoids, coumarins, glycosides, sterols, and poliasitelin have been studied in several studies [6]. Many researchers have studied the properties of herbs Binara, including antitumoral [7], anticancer, antiobesity and anti-inflammatory [8], antimicrobials [9], and antioxidant [10]. In the present study, to detect the genotoxic or carcinogenic chemicals, the micronucleus (MN) assay was used. This method was first proposed by Schmid and is applicable both in vitro and in vivo conditions [11].

Based on the principle of MN assay, in the anaphase of chromatids, the chromosome fragments became eccentric due to exposure to chemicals or ionizing radiation, while the centric chromosomes move to the spindle poles. After telophase, the remaining fragments deform to a one or more secondary cores that is called MN. This method can be used in proliferating tissues such as liver, bone marrow cells, peripheral blood, and cultured cells, although it is preferable to use the bone marrow [12]. The frequency of erythrocyte MN in bone marrow cells reflects the chromosomal abnormality induced by chemical agents.

\section{METHODS}

Materials

Drugs and chemicals used in this study were, aquades, ethanol $96 \%$, $\mathrm{NaCl}$, carboxymethylcellulose (CMC), stain Giemsa, fetal bovine serum, and cyclophosphamide (Cyclovid ${ }^{\circledR}$ ).

\section{Preparation of extracts}

A. vulgaris L. was collected from Sidomulyo village, Biru-biru subdistrict, Deli Serdang district, Sumatera Utara Province, Indonesia. The herb identification is done at "Herbarium Bogoriense" center of biological research Lembaga Ilmu Pengetahuan Indonesia Cibinong Science Center, Jl. Raya Jakarta-Bogor KM. 46 Cibinong 16911. The herbs were washed and dried at $30-35^{\circ} \mathrm{C}$, then grind until the dried powder was obtained. The dried powder was macerated used ethanol $96 \%$; , then the obtained macerate was evaporated and freeze-dried [13].

\section{Animals}

Animals used were healthy male mice weighing 25-30 g in suitable cages, given appropriate food and drink, acclimatized for 2 weeks 
before being treated. The animal experiment was approved by the Ethics Committee of the Institute No. 528/KEPH-FMIPA/2017.

\section{Preparation of CMC suspension $\mathbf{0 . 5 \%}$}

A total of $0.5 \mathrm{~g} \mathrm{CMC}$ is sown in a mortar containing $\pm 10 \mathrm{ml}$ of hot distilled water. Silenced for $15 \mathrm{~min}$, then crushed until a transparent mass is obtained, then crushed until homogeneous, diluted with distilled water, homogenized and fed into a $100 \mathrm{ml}$ tin flask, sufficient volume with distilled water to the mark line.

Preparation of Binara herbs ethanol extract suspension (BHEE) Each extract was prepared with CMC $0.5 \%$ with different doses, 100 , 200 , and $300 \mathrm{mg} / \mathrm{kg}$. Each dose was weighed and mixed with CMC $0.5 \%$ homogeneous to $10 \mathrm{ml}$ volume.

\section{Preparation of cyclophosphamide suspension}

Weigh the cyclophosphamide powder to $200 \mathrm{mg}$ inserted in the flacon added $5 \mathrm{ml} \mathrm{NaCl}, 0.45 \%$ the homogeneous and then the volume is $10 \mathrm{ml}$.

\section{MN test}

A total of 25 male mice (Mus musculus) were equally divided into five groups. The first group served as the control group and given $0.5 \%$ CMC suspension for 7 days orally. In the second group (negative control) given $0.5 \%$ CMC suspension for 7 days orally and after day $7^{\text {th }}$ induced cyclophosphamide $(50 \mathrm{mg} / \mathrm{kg})$ IP. In the third group, $100 \mathrm{mg} / \mathrm{kg} /$ day of the herb binara ethanol extract was orally for 7 days and after day $7^{\text {th }}$ induced cyclophosphamide $(50 \mathrm{mg} / \mathrm{kg})$ IP. In the $4^{\text {th }}$ Group, $200 \mathrm{mg} / \mathrm{kg} /$ day of the herb binara ethanol extract was orally for 7 days and after day $7^{\text {th }}$ induced cyclophosphamide $(50 \mathrm{mg} / \mathrm{kg}$ ) IP. In the $5^{\text {th }}$ Group, $300 \mathrm{mg} / \mathrm{kg} /$ day of the herb binara ethanol extract was orally for 7 days and after day $7^{\text {th }}$ the induced cyclophosphamide $(50 \mathrm{mg} / \mathrm{kg}$ ) IP. In all groups, $30 \mathrm{~h}$ after cyclophosphamide injection IP, the mice were killed through the cervical spinal cord transection. Both femoral bones were removed completely; then the epiphyseal portions were isolated (15). Bone marrow was gently aspirated by means of a syringe containing $1 \mathrm{ml}$ of fetal bovine serum. The suspension was collected in a test tube and centrifuged at 1500 RPM for 5 min. After the centrifuged solid part is taken and applied to the glass object. Slide is dried, fixed with methanol for 5 min. Giemsa staining was left for 10 min, dyed with aquadest, dried and observed in a microscope with a magnification of $10 \times 40$ with immersion oil for $\mathrm{MN}$ in polychromatic erythrocytes (PCEt) [14]

\section{Statistical analysis}

We used one-way analysis of variance (ANOVA) and post hoc tests for showing a significant difference between the groups and to indicate in which groups of 0.05 (95\% confidence interval), the differences are significant.

\section{RESULT}

Here is a picture of cells in the smear observation femur bone marrow of mice by light microscopy using Giemsa staining with a magnification of $400 \times$ (Fig. 1)

As can be seen in Table 1, there is a significant difference between cyclophosphamide and control group $(\mathrm{p}<0.05)$. Data show that cyclophosphamide increases the frequency of MN and decreases cell proliferation. This study showed no significant difference between BHEE and control group on the MnPCE frequency and cell proliferation ratio (PCE/PCE + normochromatic erythrocytes [NCE]) ( $<<0.05)$. Therefore, in this study, the dosage of selected BHEE did not have a clastogenic and cytotoxic effect (Table 1).

Fig. 2 shows that the number of MN in the polychromic erythrocyte cell of the normal control group is not significantly different from the number of MN in the PCE cell of the BHEE administration group of $300 \mathrm{mg} / \mathrm{kg}$ dose. Decrease in the number of MnPCE decreases with increasing dose of BHEE. Giving BHEE dose of $300 \mathrm{mg} / \mathrm{kg}$ gives the most effective effect of decreasing the number of MN
Fig. 3 shows the ratio of PCE/PCE+NCE between normal controls and giving BHEE $300 \mathrm{mg} / \mathrm{kg}$ equal. Compared to the ratio of PCE/PCE+NCE negative control with BHEE administration, there was an increase in the ratio with increasing doses of BHEE, although in the BHEE dose of $200 \mathrm{mg} / \mathrm{kg}$ there was a slight decrease in the ratio but not below the negative control ratio. Increase in PCE/PCE+NCE ratio indicates that BHEE administration reduces MN formation and cell proliferation

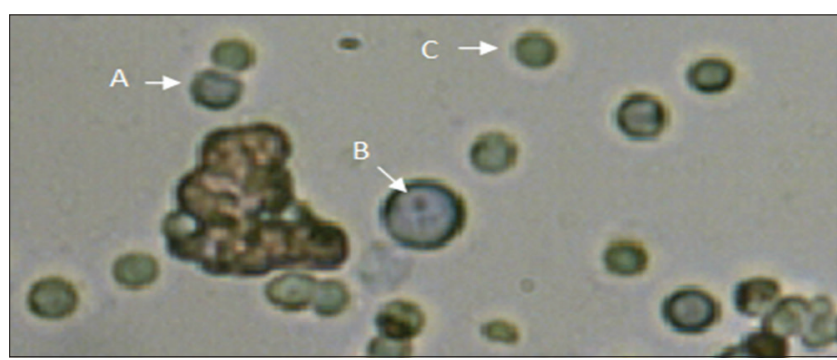

Fig. 1: Bone marrow cells: (a) Polychromatic erythrocytes (PCE), (b) larger cells containing micronucleus PCE, and (c) normochromatic erythrocytes

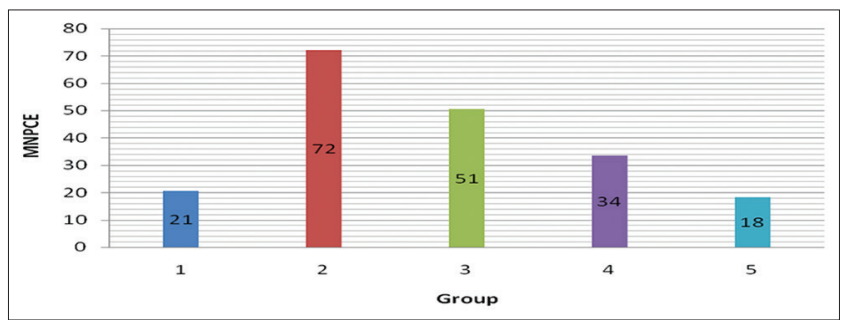

Fig. 2: Frequency changes of micronucleus polychromatic erythrocytes in the control group, cyclophosphamide, and varying concentrations of extra erythrocytic hemoglobin



Fig. 3: Variation of cell proliferation (polychromatic erythrocytes [PCE]/PCE+normochromatic erythrocytes) in the control group, cyclophosphamide, and diverse concentrations of binara herbs ethanol extract

\section{DISCUSSION}

In this study, to reduce cell damage in this case gene mutations induced by cyclophosphamide used BHEE. This can be seen from the frequency of MNPCE, and the ratio of PCE/PCE+NCE in which increased BHEE dose decreases the MnPCE frequency and increases the PCE/PCE+NCE ratio (Table 1 and Fig. 1).

Cyclophosphamide is an alkylating agent that produces free radicals. These unstable molecules alkylate the guanine base in n-7 location of the DNA arm, leading to cross-linkage between DNA arms and crushing the DNA molecules, causing mutation [15]. One of the most important methods against mutation is to trap these free radicals [16]. GamalEldeen et al. showed that algae Sargassum dentifolium has the ability to collect the $\mathrm{OH}$ radicals and active oxygens so has a protective effect against cyclophosphamide-induced abnormalities [17]. Zhang et al. 
Table 1: The mean data of MnPCE in 200 PCE cells and PCE/PCE+NCE ratios

\begin{tabular}{lll}
\hline Group & Treatment & MnPCE \pm SD \\
\hline I & CMC 0.5\% & $20.6 \pm 2.7$ \\
II & CMC 0.5\%+cyclophosphamide $(50 \mathrm{mg} / \mathrm{kg})$ & $72.2 \pm 7.05$ \\
III & BHEE $(100 \mathrm{mg} / \mathrm{kg} /$ day)+cyclophosphamide $(50 \mathrm{mg} / \mathrm{kg})$ & $50.6 \pm 5.86$ \\
IV & BHEE $(200 \mathrm{mg} / \mathrm{kg} /$ day)+cyclophosphamide $(50 \mathrm{mg} / \mathrm{kg})$ & $33.6 \pm 8.44$ \\
V & BHEE (300 mg/kg/day)+cyclophosphamide $(50 \mathrm{mg} / \mathrm{kg})$ & $18.4 \pm 2.30$ \\
\hline
\end{tabular}

BHEE: Binara herbs ethanol extract, CMC: Carboxymethylcellulose. MnPCE: Micronucleus polychromatic erythrocytes, PCE: Polychromatic erythrocytes, SD: Standard deviation, NCE: Normochromatic erythrocytes

worked on ginsenoside, a triterpene of ginseng plant, which reduces the deleterious effects of cyclophosphamide on DNA, apoptosis of bone marrow cells, and peripheral blood lymphocytes [18]. Antioxidant therapy is vital in scavenging free radicals; plant-derived antioxidants are capable to check the formation of free radicals, which reacts with biomolecules such as DNA and proteins [19]. In this study, BHEE has excellent antioxidant properties. Important components of the BHEE are flavonoids, asetilin, coumarin, lactone sesquiterpenes, and essential oils [20]. A. vulgaris has a high phenolic content and has antioxidant properties [21]. BHEE with decreased MnPCE frequency and increased PCE/PCE+NCE have a good effect on toxicity due to cyclophosphamide. As shown in Table 1, the oral dose of ethanol extract herb binara of 300 $\mathrm{mg} / \mathrm{kg}$ bin could decrease the MnPCE frequency from 72.2 to 18.4 and increase the cell proliferation ratio (PCE/PCE+NCE) from 0.42 to 0.51 statistically significant $(\mathrm{p}<0.05)$.

\section{CONCLUSIONS}

In general, the results of this study are as follows:

1. An ethanol extract of binara herbs can protect bone marrow cells of mice against cyclophosphamide-induced cytotoxicity.

2. An ethanol extract of binara herbs has antimutagenic properties.

3. The most effective dose extract of binara herbs is $300 \mathrm{mg} / \mathrm{kg}$.

\section{ACKNOWLEDGMENTS}

The authors gratefully acknowledge all the parties involved in this research, especially to all pharmacology laboratory staff of the Pharmacy Faculty of Universitas Sumatera Utara.

\section{REFERENCES}

1. Bhattacharya S. Natural antimutagens: A review. Res J Med Plants 2015;5:116-126.

2. Hales BF, Barton TS, Robaire B. Impact of paternal exposure to chemotherapy on offspring in the rat. J Natl Cancer Inst 2005;34:28-31.

3. Qiu J, Hales BF, Robaire B. Damage to rat spermatozoa DNA after chronic cyclophosphamide exposure. Biol Reprod 1995;53:1465-73.

4. Kern JC, Kehrer JP. Acrolein-induced cell death: A caspase-influenced decision between apoptosis and oncosis/necrosis. Chem Biol Interact 2002;139:79-95.

5. Bergamini CM, Gambetti S, Dondi A, Cervellati C. Oxygen, reactive oxygen species and tissue damage. Curr Pharm Des 2004;10:1611-26.

6. Tan RX, Zheng WF, Tang HQ. Biologically active substances from the genus Artemisia. Plants Med 1998;64:295-302.

7. Sun WC, Han, JX, Yang WY, Deng DA, Yue XF. Antitumor activities of 4 derivatives of artemisic acid and artemisinin in vitro. Acta Pharmacol 1992;13:541-3.

8. Choi E, Park H, Lee J, Kim G. Anticancer, antiobesity, and anti-inflammatory activity of artemisia species in vitro. J Tradit Chin Med 2013;33:92-7.

9. Kaban R. Uji Aktivitas Antibakteri Ekstrak Etanol Daun Binara dan Ekstrak Etanol Daun Ulam-ulam Terhadap Bakteri Staphylococcus aureus dan Escherichia coli. Skripsi. Fakultas Farmasi Universitas Sumatera Utara; 2015.

10. Bangol E, Momuat LI, Abidjulu J. Antioxidant activity the ethanol and $\mathrm{N}-\mathrm{Hexane}$ extract of leaves of grass Santa Maria (Artemisia vulgaris L.) on fish oil. J Ilmiah Sains 2014;14:129-35.

11. Schmid W. The micronucleus test. Mutat Res 1975;31:9-15.

12. Müller WU, Streffer C. Micronucleus Assay. Springer: Advances in Mutagenesis Research; 1994. p. 1-134.

13. Ditjen PO. Farmakope Indonesia. Edisi Keempat. Jakarta: Departemen Kesehatan Republik Indonesia; 1995. p. 969-971, 1033

14. Krisna G, Hayashi M. In vivo rodent micronucleus assay: Protocol, conduct and data interpretation. Mutat Res 2000;455:155-66.

15. Aguilar-Mahecha A, Hales BF, Robaire B. Chronic cyclophosphamide treatment alters the expression of stress response genes in rat male germ cells. Biol Reprod 2002;66:1024-32.

16. Tiwari AK. Imbalance in antioxidant defense and human diseases: Multiple approach of natural antioxidant therapy. Curr. Sci 2001;81:1179-87.

17. Gamal-Eldeen AM, Abo-Zeid MA, Ahmed EF. Anti-genotoxic effect of the Sargassum dentifolium extracts: Prevention of chromosomal aberrations, micronuclei, and DNA fragmentation. Exp Toxicol Pathol 2013;65:27-34.

18. Zhang QH, Wu CF, Yang JY, Mu YH, Chen XX, Zhao YQ. Reduction of cyclophosphamide-induced DNA damage and apoptosis effects of ginsenoside $\mathrm{Rb} 1$ on mouse bone marrow cells and peripheral blood leukocytes. Environ Toxicol Pharmacol 2009;27:384-9.

19. Ambasta SK, Kumari S, Sinha UK. Anticlastogenicity of Tinospora cordifolia stem extract against arsenic genotoxicity in Mus musculus bone marrow erythrocytes using micronucleus assay. Int J Pharm Sci 2017;9:260-4.

20. Marco JA, Barbera O. Natural products from the genus Artemisia L. In: Atta-ur-Rahman BS, editor. Studies in Natural Products Chemistry. Vol. 7A. Amsterdam: Elsevier Science Publication; 1990. p. 201-64.

21. Irda F, Evelyne N, Komar RW. In vitro antioxidant activities, total flavanoid, phenolic and carotenoid content from various extracts of four species Asteraceae herb. Int J Pharm Sci 2015;7:192-7. 